\title{
HUBUNGAN FAKTOR SOSIAL EKONOMI DENGAN KETERSEDIAAN PANGAN RUMAH TANGGA PETANI DI KECAMATAN MALAKA TENGAH KABUPATEN MALAKA
}

\author{
${ }^{1}$ Marthen R. Pellokila, ${ }^{2}$ Grouse Oematan, ${ }^{3}$ Romi N. L. Kami \\ ${ }^{1-3}$ Program Studi Agribisnis, Fakultas Pertanian \\ ${ }^{2}$ Program Studi Ilmu Kesehatan Masyarakat, Public Health Faculty \\ Universitas Nusa Cendana \\ Author Adress : marthenrobinsonpellokila@staf.undana.ac.id
}

\begin{abstract}
ABSTRAK
$\mathrm{K}$

etersediaan pangan merupakan kondisi penyediaan pangan yang mencakup makanan dan minuman yang berasal dari tanaman, ternak dan ikan berikut turunannya bagi penduduk suatu wilayah dalam suatu kurun waktu tertentu. Ketersediaan pangan merupakan suatu sistem yang berjenjang (hierarchial systems) mulai dari nasional, propinsi (regional), lokal (kabupaten/kota) dan rumah tangga. Ketersediaan pangan dapat diukur baik pada tingkat makro maupun mikro (Baliwati dan Roosita, 2004). Ketersediaan pangan dapat terwujud melalui produksi usahatani dan nonusahatani. Ketersediaan pangan melalui usahatani dapat dilakukan melalui pengelolaan ragam faktor produksi, sedangkan ketersediaan pangan melalui non usahatani membutuhkan akses atau kemampuan dengan daya jangkau berupa daya beli atau pendapatan. Penelitian ini bertujuan untuk mengetahui hubungan antara faktor sosial ekonomi dengan tingkat ketersediaan pangan pada rumah tangga petani di Kabupaten Malaka. Data yang digunakan dalam penelitian ini ialah data sekunder dan data primer yang diperoleh dari hasil wawancara berdasarkan kuisioner. Penentuan sampel dilakukan secara bertahap (multistage random sampling) yaitu terlebih dahulu menentukan wilayah kecamatan secara acak sehingga terpilih Kecamatan Malaka Tengah dari 12 Kecamatan yang ada. Selanjutnya penentuan desa contoh yaitu Desa Wehali dan Desa Kletek dan terakhit ialah penentuan rumah tangga petani contoh (responden) dengan mengunakan rumus slovin sehinga total responden yang didapat ialah 84 responden. Selanjutnya data yang terkumpul dianalisis menggunakan analisis regresi linier berganda. Hasil analisis menunjukan bahwa faktor yang berhubungan dengan ketersediaan pangan pada rumah tangga petani pada kedua desa ialah faktor tingkat pendapatan yang memberikan pengaruh positif sedangkan jumlah anggota keluarga dan tingkat pendidikan ibu tidak memberikan pengaruh terhadap ketersediaan pangan pada rumah tangga petani.
\end{abstract}

Kata kunci : Faktor Sosial Ekonomi, Ketersediaan Pangan, Rumah Tangga Petani, Jumlah Anggota Keluarga, Tingkat Pendidikan Ibu, Tingkat Pendapatan Keluarga 


\title{
RELATIONSHIP OF SOCIAL ECONOMIC FACTORS WITH FARMER'S HOUSEHOLD FOOD AVAILABILITY IN CENTRAL MALAKA SUB-DISTRICT, MALAKA DISTRICT
}

\author{
${ }^{1}$ Marthen R. Pellokila, ${ }^{2}$ Grouse Oematan, ${ }^{3}$ Romi N. L. Kami \\ ${ }^{1-3}$ Agribusiness Study Program, Faculty of Agriculture \\ ${ }^{2}$ Public health scientific program, Public Health Faculty \\ Nusa Cendana University \\ Author Adress : marthenrobinsonpellokila@staf.undana.ac.id
}

\begin{abstract}
$F$

ood availability is a condition of providing food that includes food and beverages derived from plants, livestock and fish and their derivatives for residents of an area within a certain period of time. Food availability is a hierarchial system starting from national, provincial (regional), local (district / city) and household. Food availability can be measured at both the macro and micro levels (Baliwati and Roosita, 2004). Food availability can be realized through farm and non-agricultural production. The availability of food through farming can be done through the management of various factors of production, while the availability of food through non-farming requires access or the ability to reach the purchasing power or income. This study aims to determine the relationship between socio-economic factors and the level of food availability in farmer households in Malacca Regency. The data used in this study are secondary data and primary data obtained from interviews based on questionnaires. The sample was determined in stages (multistage random sampling), namely first determining the district area randomly so that Central Malaka District was selected from the 12 existing Districts. Furthermore, the determination of sample villages, namely Wehali and Kletek villages, and finally the determination of the sample farmer households (respondents) using the Slovin formula so that the total respondents obtained were 84 respondents. Furthermore, the collected data were analyzed using multiple linear regression analysis. The results of the analysis show that the factors related to the availability of food in farmer households in the two villages are the level of income which has a positive effect, while the number of family members and the mother's education level do not have an influence on food availability in farmer households.
\end{abstract}

Keywords : Socio-Economic Factors, Food Availability, Farm Household, Number of Family Members, Mother's Education Level, Family Income Level 


\section{PENDAHULUAN}

Ketahanan Pangan adalah kondisi terpenuhinya pangan bagi negara sampai dengan perseorangan yang dilihat dari tersedianya pangan yang cukup, baik jumlah maupun mutunya, aman, beragam, bergizi, merata, terjangkau dan tidak bertentangan dengan agama, keyakinan, serta budaya masyarakat, untuk dapat hidup sehat, aktif, dan produktif secara berkelanjutan (Undang- undang No 18 tahun 2012 ).

Ketahanan pangan meliputi tiga subsistem utama yaitu subsistem ketersediaan, aksesibilitas dan penyerapan pangan. Salah satu subsistem tersebut tidak dipenuhi maka suatu daerah belum dapat dikatakan mempunyai ketahanan pangan yang baik. Ketersediaan pangan merupakan kondisi penyediaan pangan yang mencakup makanan dan minuman yang berasal dari tanaman, ternak dan ikan berikut turunannya bagi penduduk suatu wilayah dalam suatu kurun waktu tertentu. Ketersediaan pangan merupakan suatu sistem yang berjenjang (hierarchial systems) mulai dari nasional, propinsi (regional), lokal (kabupaten/kota) dan rumah tangga. Ketersediaan pangan dapat diukur baik pada tingkat makro maupun mikro (Baliwati dan Roosita, 2004).

Ketersediaan pangan dapat terwujud melalui produksi usahatani dan nonusahatani. Ketersediaan pangan melalui usahatani dapat dilakukan melalui pengelolaan ragam faktor produksi, sedangkan ketersediaan pangan melalui non usahatani membutuhkan akses atau kemampuan dengan daya jangkau berupa daya beli atau pendapatan. Tanaman pangan yang dominan diusahakan di Kabupaten Malaka adalah jagung, disusul padi, ubi kayu, dan ubi jalar. Data memperlihatkan bahwa luas panen jagung dan padi selalu meningkat selama periode 2014-2015 dengan produksinya yang selalu berfluktuasi. Produksi jagung pada tahun 2014 mencapai peningkatan menjadi 52.414 ton kemudian produksi jagung berkurang menjadi 36.125 ton pada tahun 2015. Trend produksi yang berbeda terjadi pula pada produksi padi. Pada tahun 2015 produksi padi mengalami peningkatan menjadi 27.870 ton dari pada tahun 2014 hanya memproduksi 16.974 ton. Hal lain yang mencolok bahwa luas panen dan produksi ubi jalar menurun dengan drastis selama periode 2014-2015. Pada jenis tanaman pangan ubi kayu juga tejadi penurunan baik luas lahan maupun produksinya.

Ketahanan pangan tidak lepas dari produksi pangan yang bersifat musiman dan berfluktuasi karena dipengaruhi oleh berbagai faktor. Perilaku produksi dipengaruhi iklim sehingga mempengaruhi ketersediaan pangan. Jika perilaku produksi yang rentan terhadap perubahan iklim tersebut dan tidak dilengkapi dengan kebijakan pangan yang tangguh maka akan sangat merugikan, baik untuk produsen maupun konsumen, khususnya produsen berskala produksi kecil dan konsumen berpendapatan rendah, selain itu komoditi pangan yang mudah rusak, lahan produksi petani yang terbatas, sarana dan prasarana pendukung pertanian yang kurang memadai dan lemahnya penanganan panen dan pasca panen mendorong pemerintah untuk melakukan intervensi dengan mewujudkan kebijakan ketahanan pangan.

Trend produksi tanaman pangan yang berfluktuasi akan berpengaruh terhadap ketersedian pangan di Kabupaten Malaka. Ketersediaan pangan rumah tangga selain ditentukan oleh pangan yang berasal dari produksi usahatani juga dipengaruhi oleh 
aksesibilitas terhadap pangan. Oleh karena itu setiap rumah tangga selain berusahatani tanaman pangan, mereka mengolah tanaman perkebunan atau ternak dengan harapan mereka dapat menjual hasil usaha tersebut untuk memperoleh pendapatan. Ada pula yang bekerja diluar pertanian untuk memperoleh pendapatan yang akan digunakan untuk membeli kebutuhan pangan dan kebutuhan rumah tangga yang lain. hal ini sesuai dengan yang dinyatakan oleh Jutomo (2000) bahwa ketersediaan pangan sumber energi rumah tangga dipengaruhi oleh produksi pangan atau pendapatan. Namun dipihak lain, Roedjito (1989) menyatakan bahwa tersedianya pangan yang cukup dalam keluarga atau masyarakat, belum menjamin bahwa kebutuhan akan gizi setiap orang sudah terpenuhi. Berdasarkan uraian di atas, penulis tertarik untuk melakukan penelitian dengan tujuan mengetahui faktor-faktor yang berhubungan dengan ketersediaan pangan pada rumah tangga petani masyarakat di Kabupaten Malaka.

\section{METODE PENELITIAN}

Penelitian ini menggunakan desain Crossectional Study yaitu penelitian analitik kuantitaif yang mempelajari bagaimana hubungan antara variabel independen dengan variabel dependen yang diukur dalam sekali waktu pengukuran atau pengumpulan data (Notoatmodjo, 2014). Dalam penelitian ini yang menjadi variabel independen adalah faktor tingkat pendapatan, jumlah anggota keluarga, dan tingkat pendidikan ibu keluarga. Sedangkan yang menjadi variabel dependen adalah tingkat ketersediaan pangan pada rumah tangga petani masyarakat di Kabupaten Malaka. Penelitian ini memfokuskan pada jenis tanaman pangan yang dikonsumsi masyarakat, terutama dalam rangka untuk memenuhi kebutuhan karbohidrat keluarga.

Data yang digunakan dalam penelitian ini ialah data sekunder dan data primer yang diperoleh dari hasil wawancara berdasarkan kuisioner. Pengumpulan data dilakukan pada bulan November Tahun 2019. Penentuan sampel dilakukan secara bertahap (multistage random sampling) yaitu terlebih dahulu menentukan wilayah kecamatan secara acak sehingga terpilih Kecamatan Malaka Tengah dari 12 Kecamatan yang ada. Selanjutnya penentuan desa contoh yaitu Desa Wehali dan Desa Kletek dan terakhit ialah penentuan rumah tangga petani contoh (responden) dengan mengunakan rumus slovin sehinga total responden yang didapat ialah 84 responden. Selanjutnya data yang terkumpul dianalisis menggunakan analisis regresi linier berganda untuk mencari nilai $\mathrm{P}$ value $<0,05$. Pada variabel yang mempunyai hubungan dengan nilai $\mathrm{P}$ value $<0,05$, akan dilanjutkan dengan analisis multivariat dan nilai Rsquare (Tjahjono, 2011).

\section{HASIL DAN PEMBAHASAN}

1. Karakteristik Variabel Independet

\subsection{Tingkat Pendidikan}

Pola berpikir petani dalam mengelola usahataninya sangat ditentukan oleh tingkat pendidikan yang dicapai, baik tingkat pendidikan formal maupun non formal. Petani dengan tingkat pendidikan yang lebih tinggi memiliki pola berpikir yang dinamis sehingga lebih inovatif, terampil dan dapat dengan mudah mengelola usahataninya. 
Tingkat pendidikan petani didaerah penelitian sangat bervariasi mulai dari tidak bersekolah (buta huruf) sampai sarjana, seperti yang disajikan pada Tabel 1.

Tabel 1. Distribusi responden Berdasarkan Tingkat Pendidikan Formal pada Dua Desa Contoh di Kabupaten Malaka

\begin{tabular}{|c|c|c|c|c|c|c|c|}
\hline \multirow{3}{*}{ No } & \multirow{3}{*}{$\begin{array}{c}\text { Pendidikan } \\
\text { Formal }\end{array}$} & \multicolumn{4}{|c|}{ Desa } & \multirow{2}{*}{\multicolumn{2}{|c|}{ Jumlah }} \\
\hline & & \multicolumn{2}{|c|}{ Wehali } & \multicolumn{2}{|c|}{ Kletek } & & \\
\hline & & $\mathrm{n}$ & $\%$ & $\mathrm{n}$ & $\%$ & $\mathrm{n}$ & $\%$ \\
\hline 1. & Tidak Sekolah & 2 & 6,3 & 24 & 46.2 & 26 & 31,0 \\
\hline 2. & SD & 18 & 56,3 & 16 & 30.8 & 34 & 40,5 \\
\hline 3. & SMP & 6 & 18,8 & 8 & 15.4 & 14 & 16,7 \\
\hline 4. & SMA & 5 & 15,6 & 4 & 7.7 & 9 & 10,7 \\
\hline 5. & Perguruan Tinggi & 1 & 3,1 & - & - & 1 & 1,2 \\
\hline & Jumlah & 32 & 100 & 52 & 100 & 84 & 100 \\
\hline
\end{tabular}

Sumber: Data Primer Diolah, 2018

Tabel 1 menunjukkan bahwa tingkat pendidikan formal yang dimiliki responden tergolong rendah dimana petani responden tidak tamat sekolah sebanyak 26 orang (31\%), tamatan SD sebanyak 34 orang (40,5\%), tamatan SMP 14 orang (16,7\%), tamatan SMA 9 orang $(10,7 \%)$, dan tamatan Perguruan Tinggi 1 orang $(1,2 \%)$. Bila dibandingkan antar desa, di Desa Wehali sebesar (56,3\%) adalah tamatan SD, (6,3\%) tidak bersekolah sedangkan hanya $(3,1 \%)$ responden tamatan Perguruan Tinggi; di Desa Kletek persentase penduduk dengan tingkat pendidikan SD sebesar (30,8\%) sedangkan tidak bersekolah $(46,2 \%)$ dan tamatan SMA hanya $(7,7 \%)$ saja. Dengan demikian, tingkat pendidikan formal yang rendah ini disebabkan oleh kurangnya pemahaman tentang pentingnya pendidikan dan adanya biaya pendidikan yang mahal serta fasilitas dan sarana yang kurang memadai.

\subsection{Jumlah Anggota Keluarga}

Kebutuhan hidup suatu rumah tangga ditentukan oleh besar kecilnya jumlah anggota keluarga yang selanjutnya berpengaruh terhadap tingkat keberlangsungan hidup rumah tangga tersebut. Semakin banyak anggota rumah tangga maka semakin tinggi kebutuhan hidup rumah tangga tersebut. Anggota rumah tangga terdiri dari suami, istri, anak, maupun orang lain yang tinggal menetap dalam satu atap, yang kehidupannya (sandang, pangan dan papan) tergantung pada penghasilan dari rumah tangga tersebut. Penggelompokkan tanggungan rumah tangga dibagi menjadi tiga kategori yaitu kecil jika tanggungannya kurang dari empat orang, sedang jika tanggungannya empat sampai enam orang dan besar jika tanggungan rumah tangganya lebih dari enam orang.

Tabel 2. Distribusi Responden Berdasarkan Jumlah Tanggungan Keluarga pada Dua Desa Contoh di Kabupaten Malaka

\begin{tabular}{|c|c|c|c|c|c|c|c|}
\hline \multirow{2}{*}{ No } & \multirow{2}{*}{$\begin{array}{c}\text { Jumlah Tanggungan } \\
\text { Keluarga }\end{array}$} & \multicolumn{4}{|c|}{ Desa } & \multicolumn{2}{|c|}{ Jumlah } \\
\cline { 3 - 8 } & & \multicolumn{2}{|c|}{ Wehali } & \multicolumn{2}{c|}{ Kletek } & & \\
\cline { 3 - 8 } & & $\mathrm{n}$ & $\%$ & $\mathrm{n}$ & $\%$ & $\mathrm{n}$ & $\%$ \\
\hline & Nuclear Family (4 orang) & 12 & 42.9 & 16 & 57.1 & 28 & 100 \\
\hline & Exteendet Family (> 4 orang) & 20 & 35.7 & 36 & 64.3 & 56 & 100 \\
\hline & Jumlah & 32 & 100 & 52 & 100 & 84 & 100 \\
\hline
\end{tabular}

Sumber: Data Primer Diolah, 2018 
Hasil penelitian menunjukan bahwa rata-rata jumlah tanggungan rumah tangga responden pada kedua desa sampel yakni sebanyak 5 orang. Hasil penelitian menjelaskan bahwa keluarga dengan anggota rumah tangga yang banyak, belum menjamin semua anggota rumah tangga membantu di lahan usahatani. Hal ini dikarenakan anggota keluarganya secara fisik masih kecil dan masih bersekolah. Tabel 2 menunjukan bahwa 42.9\% responden di Desa Wehali mempunyai jumlah anggota keluarga sebanyak empat (4) orang atau "nuclear family" (keluarga kecil). Sedangkan di desa Kletek sebagian besar (64.3\%) memiliki jumlah tanggungan rumah tangga yang banyak (lebih dari empat orang/Extendet Family). Responden dengan jumlah tanggunan yang banyak cenderung memiliki pengeluaran yang besar pula. Namun jumlah tanggungan keluarga yang banyak juga menjadi salah satu faktor penentu dalam berusahatani, dimana anggota keluarga yang terlibat dalam kegiatan usahatani dapat memberikan kontribusi waktu dan tenaganya yang bertujuan untuk meminimalkan pengeluaran untuk usahatani tersebut khususnya dalam membiayai buruh tani dan berdampak pada pendapatan rumah tangga.

\subsection{Tingkat Pendapatan Keluarga}

Pendapatan rumah tangga petani pedesaan dapat mencerminkan keadaan ekonomi rumah tangga. Tinggi rendahnya tingkat pendapatan rumah tangga petani pedesaan dapat memperlihatkan tingkat kesejahteraan suatu rumah tangga (Khususiyah et. al., 2010 dalam Yulian et.al, 2016). Secara agregat pendapatan rumah tangga petani pedesaan di Kabupaten Malaka diperoleh dari tiga sumber pendapatan, yaitu sumber pendapatan dari pertanian, pendapatan non-pertanian dan pendapatan lainnya. Sumber pendapatan pertanian diperoleh dari kegiatan usaha tani tanaman pangan, holtikultura, perkebunan, dan kehutanan yang merupakan sumber pendapatan pokok dan memelihara ternak/unggas. Sedangkan sumber pendapatan dari non-pertanian diperoleh dari bekerja sebagai ojek, supir/konjak, tukang bangunan, menenun, berdagang, pegawai swasta, aparat desa, honorer dan pensiunan. Sedangkan sumber pendapatan lainnya diperoleh dari bantuan pemerintah berupa Bantuan Langsung Tunai (BLT) dan Program Keluarga Harapan $(\mathrm{PKH})$ untuk rumah tangga yang memiliki anak usia sekolah dengan kriteria penerima bantuan sesuai dengan yang telah ditetapkan pemerintah dan pendapatan lainnya juga diperoleh dari kiriman tunai oleh kerabat yang bekerja di luar daerah atau luar negeri.

Tabel 3. Struktur Rata-Rata Pendapatan Rumah Tangga Petani Pedesaan Berdasarkan Sumber Pendapatan pada Dua Desa Contoh di Kabupaten Malaka (dalam Rp/Bulan)

\begin{tabular}{|c|r|r|r|r|}
\hline \multirow{2}{*}{ SUMBER PENDAPATAN } & \multicolumn{2}{|c|}{ DESA WEHALI } & \multicolumn{2}{c|}{ DESA KLETEK } \\
\cline { 2 - 5 } & \multicolumn{1}{|c|}{$\mathrm{Rp}$} & \multicolumn{1}{c|}{$\%$} & \multicolumn{1}{c|}{$\mathrm{Rp}$} & \multicolumn{1}{c|}{$\%$} \\
\hline I. Pertanian & & & & \\
\hline - Tanaman Pangan & 280.188 & 33,68 & 292.091 & 26,51 \\
\hline - Holtikultura & 8.938 & 1,07 & 4.242 & 0,39 \\
\hline - Perkebunan & 203.625 & 24,47 & 90.394 & 8,21 \\
\hline - Kehutanan & 5.875 & 0,71 & 6.273 & 0,57 \\
\hline - Peternakan & 6.250 & 0,75 & 15.273 & 1,39 \\
\hline Total & 504.875 & 60,68 & 408.273 & 37,06 \\
\hline II. Non-Pertanian & & & & \\
\hline - Ojek & 40.625 & 4,88 & 46.970 & 4,26 \\
\hline - Sopir/Konjak & 31.250 & 3,76 & & - \\
\hline
\end{tabular}




\begin{tabular}{|c|r|r|r|r|}
\hline \multirow{2}{*}{ SUMBER PENDAPATAN } & \multicolumn{2}{|c|}{ DESA WEHALI } & \multicolumn{2}{c|}{ DESA KLETEK } \\
\cline { 2 - 5 } & \multicolumn{1}{|c|}{$\mathrm{Rp}$} & \multicolumn{1}{c|}{$\mathrm{Rp}$} & \multicolumn{1}{c|}{$\%$} \\
\hline - Tukang & - & - & 100 & 9,08 \\
\hline - Menenum & 111.563 & 13,41 & 74.394 & 6,75 \\
\hline - Berdagang & - & - & 45.455 & 4,13 \\
\hline - Pegawai Swasta & 62.500 & 7,51 & 15.909 & 1,44 \\
\hline - Aparat Desa & - & - & 90.909 & 8,26 \\
\hline - Honorer & - & - & 7.576 & 0,69 \\
\hline - Pensiunan & - & - & 6.061 & 0,55 \\
\hline Total & 245.938 & 29,56 & 387.273 & 35,16 \\
\hline III. Pendapatan Lain & & & & \\
\hline - Bantuann Pemerintah & 62.500 & 7,51 & 37.121 & 3,37 \\
\hline - BLT & - & - & 4.545 & 0,41 \\
\hline - PKH & 62.500 & 7,51 & 32.576 & 2,96 \\
\hline - Kerabat & 18.750 & 2,25 & 268.939 & 24,41 \\
\hline Total & 81.250 & 9,76 & 306.061 & 27,78 \\
\hline TOTAL PENDAPATAN & 832.063 & 100 & 1.101 .606 & 100 \\
\hline Sumber: Data Primer Diolah, 2018 & & & & \\
\hline
\end{tabular}

Ditinjau dari segi pendapatan relatif antar sumber selama 1 bulan pada Tabel 3, nampak bahwa sumber pendapatan dari pertanian di dua desa contoh masih cukup menonjol dari total pendapatan rumah tangga petani. Desa dengan pendapatan dari sumber pertanian terbesar yakni Desa Wehali; dimana pendapatan Desa Wehali yaitu Rp. 504.875 .

Tabel 3 menunjukan bahwa desa contoh yaitu Desa Wehali di Kecamatan Malaka Tengah dengan karakteristik luas wilayah sebesar $6,1 \mathrm{~km} 2$ memiliki pendapatan pertanian yang lebih tinggi bila dibandingkan dengan desa Kletek. Hal ini karena cuaca di Desa Wehali lebih cocok untuk daerah pertanian karena tanahnya lebih subur sehingga usahatani dapat dilakukan hingga dua kali musim tanam khususnya untuk tanaman pangan dan memiliki lebih banyak komoditi untuk diusahakan baik komoditi holtikultura, perkebunan maupun kehutanan didukung dengan lahan pengembalaan peternakan yang luas sedangkan di Desa Kletek cuacanya cenderung panas dan gersang karena daerahnya dekat dengan pantai sehingga kondisi tanahnya kering untuk itu usahatani dilakukan bila menjelang musim hujan saja. Namun pendapatan pertanian dari ke dua desa ini ditopang oleh pendapatan dari perkebunan dan kehutanan. Dengan demikian dapat disimpulkan bahwa sektor pertanian masih tetap menjadi tulang punggung sumber pendapatan rumah tangga petani pada dua desa contoh di Kecematan Malaka Tengah .

Sumber pendapatan dari non pertanian juga cukup memberi kontribusi yang besar terhadap total pendapatan rumah tangga petani pedesaan pada dua desa contoh di Kabupaten dimana kontribusi sektor non pertanian ini yaitu sebesar 29,56\% di Desa Wehali; 35,16\%. Bila dibandingkan antar desa contoh, kontribusi pendapatan terbesar dari sumber non pertanian terdapat di Desa Kletek dibandingkan di Desa Wehali. Hal ini karena pendapatan yang rendah dari sumber pertanian di Desa Kletek mengharuskan petani dan anggota rumah tangganya untuk mencari tambahan pendapatan melalui kegiatan lain di luar bertani dan beternak. Hal yang sama juga terjadi di Desa Wehali namun persentase pendapatannya masih lebih rendah dibanding Desa Kletek. 
Bila dibandingkan antarsumber non pertanian pada masing-masing desa contoh maka kontribusi pendapatan dari tukang bangunan adalah yang terbesar di Desa Kletek dengan persentase 9,08\% sedangkan di Desa Wehali kontribusi pendapatan terbesar dari sumber non pertanian yaitu dari Menenun dengan persentase sebesar 13,41\%. Selanjutnya Kontribusi pedapatan dari sumber non pertanian terkecil disumbangkan oleh pensiunan dengan persentase $0,55 \%$ dari total 8 jenis kegiatan non pertanian yang dikerjakan untuk pendapatan rumah tangga petani di Desa Kletek,.

Dapat dilihat juga pada Tabel 3, bahwa di Desa wehali pendapatan dari kegiatan menenum memberi kontribusi yang cukup besar terhadap pendapatan rumah tangga dengan persentase sebesar 13, 41\%. Angka ini jauh lebih besar dibandingkan dengan Desa Kletek yang hanya 6,75\%. Hal ini dikarenakan kegiatan menenun di Desa Wehali berorientasi pada pasar sehingga banyak rumah tangga yang menjual hasil tenunnya ke pasar maupun ke pengumpul sedangkan di Desa Kletek, hasil tenun hanya dimaksudkan untuk digunakan sendiri untuk upacara adata dan dijual hanya bila ada yang langsung membeli atau dipesan terlebih dahulu sehingga pendapatan dari kegiatanan menenun di Desa Kletek yaitu Rp. 74.394 atau 6,75 \%. Proses penenunan yang lama membuat mereka berpikir bahwa hasil menenun sebaiknya hanya digunakan sendiri dari pada dijual dan pendapatan yang diterima tidak sebanding dengan proses dan biaya yang mereka keluarkan.

Pendapatan dari sumber lainnya terdiri dari bantuan pemerintah dan kiriman kerabat. Bantuan pemerintah memberi kontribusi terhadap total pendapatan rumah tangga sebesar $9.76 \%$ di Desa Wehali; 27,78\% di Desa Kletek. Bila dibandingkan antar desa, dapat dilihat bahwa kontribusi pendapatan terbesar dari bantuan pemerintah terhadap total pendapatan rumah tangga petani terdapat di Desa Kletek dengan rata-rata pendapatan sebesar Rp. 387.273, hal ini dikarenakan dari 52 rumah tangga petani di Desa Kletek, 7 rumah tangga petani diantaranya mendapat bantuan Program Keluarga Harapan (PKH) dan 1 rumah tangga juga mendapatan Bantuan Langsung Tunai (BLT). Sedangkan kontribusi pendapatan terendah dari bantuan pemerintah yaitu di Desa wehali karena dari 32 rumah tangga petani tidak ada yang mendapat bantuan BLT dan hanya 4 rumah tangga saja yang mendapat bantuan PKH.

Pendapatan dari sumber lain yang ke-dua yaitu pendapatan yang diperoleh dari kiriman kerabat yang bekerja di luar daerah atau luar negeri. Pendapatan dari kiriman kerabat ini memberi kontribusi terhadap total pendapatan rumah tangga sebesar 2,25\% di Wehali; 24,41\%. Desa Kletek menjadi desa dengan persentase kiriman kerabat terbesar terhadap total pendapatan rumah tangga petani karena banyaknya anggota rumah tangga di desa ini yang berkerja di luar daerah dan luar negeri dengan jumlah kiriman yang lebih besar. Sedangkan persentase pendapatan dari sumber kiriman kerabat terhadap total pendapatan rumah tangga yang terkecil terjadi di Wehali karena dari 32 rumah tangga, hanya 2 rumah tangga saja yang mendapat kiriman uang dari kerabat.

Dengan melihat masih besarnya kontribusi sektor pertanian terhadap total pendapatan rumah tangga petani pedesaan di Kabupaten maka sektor ini masih menjadi penopang utama kehidupan petani di pedesaan. Namun bila melihat kontribusi pendapatan dari sumber non pertanian dan sumber lainnya menandakan telah terjadi 
diversifikasi peluang kerja di luar sektor pertanian yang dapat dimanfaatkan untuk memperoleh pendapatan tambahan demi memenuhi kebutuhan hidup anggota rumah tangga baik itu dilakukan dengan bekerja di dalam desa atau bermigrasi dan bekerja di luar desa seperti anggota rumah tangga yang bekerja sebagai tenaga kerja Indonesia (TKI) dan tenaga kerja wanita (TKW).

2. Hubungan antara Faktor Sosial Ekonomi dengan Tingkat Ketersediaan Pangan Keluarga Sampel

Untuk mengetahui pengaruh dari faktor-faktor ketersediaan pangan di kabupaten Malaka maka dalam penelitian ini dianalisis menggunakan analisis regresi linear berganda. Hasil analisis regresi linear berganda di sajikan pada Tabel 4.

Tabel 4 : Hasil Analisis Regresi Ketersediaan Pangan Di Desa Wehali Dan Desa Kletek Kecamatan Malaka Tengah Kabupaten Malaka

\begin{tabular}{|c|r|r|r|}
\hline Variabel & $\begin{array}{c}\text { Koeisiensi } \\
\text { Regresi }\end{array}$ & \multicolumn{1}{|c|}{ T-Hitung } & Signifikan \\
\hline Konstanta & -818.692 .660 & $-0,791$ & 0,431 \\
\hline Pendapatan (X1 ) & 0,017 & 1.783 & 0,078 \\
\hline Jumlah Tanggungan( X2 ) & 102.902 .887 & 1.092 & 0,278 \\
\hline pendidikan Ibu (X3 ) & 39.729 .533 & 0,699 & 0,486 \\
\hline$F_{\text {hitung }}=16,135$ & & \multicolumn{2}{|c}{ R Adjusted Squere $=0,505$} \\
$R^{2}=0,538$ & & \multicolumn{2}{|c}{} \\
\hline
\end{tabular}

Hasil analisis dalam penelitian ini menunjukkan bahwa nilai $\mathrm{R}^{\wedge} 2$ sebesar 0,538. Dari hasil tersebut diketahui bahwa kemampuan variable-variabel bebas untuk menjelaskan variable terikat sebesar 53,8\%. Sedangkan sisanya sebesar 46,2\% dijelaskan oleh variabel-variabel yang tidak dimasukan dalam model. Selanjutnya, hasil analisis Anova disajikan menunjukan bahwa nilai $F$ hitung 16,135 signifikan pada $\alpha 0,01$ sehingga dapat disimpulkan bahwa ketiga yang di masukan dalam model secara bersamasama berpengaruh nyata terhadap ketersediaan pangan rumahtangga petani di Kabupaten Malaka.

\section{Tingkat Pendapatan}

Hasil analisis regresi menunjukkan bahwa nilai t hitung sebesar 1.783 signifikan pada 0,078 sehingga dapat disimpulkan bahwa variabel pendapatan berpengaruh secara signifikan terhadap tingkat ketersediaan pangan rumah tangga.Nilai koefisien regresi pendapatan sebesar 0,017 menunjukan bahwa apabila pendapatan bertambah satu rupiah akan meningkatkan ketersediaan pangan sebesar $0.017 \mathrm{Kkal}$ dengan asumsi variabel lain konstan. Hal ini dapat dijelaskan bahwa dengan dengan adanya peningkatan pendapatan artinya kemampuan atau daya beli masyarakat terhadap bahan pangan juga tinggi sehingga kebutuhan atau ketersediaan pangan dengan sendirinya dapat terpenuhi.

\section{Jumlah Anggota Keluarga}

Hasil analisis regresi menunjukkan bahwa nilai t hitung sebesar 1.092 tidak signifikan pada $\alpha=10 \%$, sehingga dapat disimpulkan bahwa variabel jumlah 
tanggungan rumah tangga berpengaruh tidak nyata terhadap ketersediaan pangan rumahtangga petani. Namun nilai koefisien regresi rumahtangga bernilai positif sebesar 102,902 mengindikasikan bahwa ada kecenderungan rumahtangga yang memiliki jumlah tanggungan anggota rumahtangga yang besar memiliki tingkat ketersediaan pangan yang lebih tinggi.Selain itu terjadinya kondisi ini juga diduga karena tidak semua anggota rumahtangga berstatus sebagai tenaga kerja produktif melainkan masih berstatus anak dan ada yang masih sekolah sehingga tidak bisa terlibat langsung dalam kegiatan produksi tanaman pangan yang dapat berpangaruh positif terhadap tingkat ketersediaan pangan rumahtangga.

\section{Tingkat Pendidikan Ibu Keluarga}

Hasil analisis regresi menunjukkan bahwa nilai t hitung sebesar 0,699 tidak signifikan pada $\alpha=10 \%$, sehingga dapat disimpulkan bahwa variabel tingkat pendidikan ibu rumahtangga berpengaruh tidak nyata terhadap ketersediaan pangan rumahtangga petani. Namun nilai koefisien regresi tingkat pendidikan Ibu bernilai positip sebesar 39,729 mengindikasikan bahwa ada kecenderungan rumahtangga yang memiliki ibu rumahtangga yang berpendidikan tinggi memiliki tingkat ketersediaan pangan yang lebih tinggi., karena ibu rumahtangga yang berpendidikan tinggi memiliki pengetahuan yang lebih baik dalam mengatur menu makanan rumahtangga maupun berusaha untuk mendapatkan pangan yang dapat meningkatkan ketersediaan pangan rumahtangga.

\section{PENUTUP}

\section{SIMPULAN}

Berdasarkan penelitian yang dilakukan, maka dapat disimpulkan bahwa :

1. Rerata ketersediaan pangan rumah tangga petani di kedua desa sampel adalah 9.699 Kkal atau rerata untuk keluarga kecil adalah 2.425 Kkal per individu per hari dan keluarga besar adalah $1.940 \mathrm{Kkal}$ per individu per hari.

2. Rerata ketersediaan pangan rumah tangga petani di desa Wehali adalah 8.691 Kkal atau atau rerata untuk keluarga kecil adalah $2.172 \mathrm{Kkal}$ per individu per hari dan keluarga besar adalah $1.739 \mathrm{Kkal}$ per individu per hari.

3. Rerata ketersediaan pangan rumah tangga petani di desa Kletek adalah $10.533 \mathrm{Kkal}$ atau atau rerata untuk keluarga kecil adalah 2.633 Kkal per individu per hari dan keluarga besar adalah 2.107 Kkal per individu per hari.

4. Faktor yang mempengaruhi ketersediaan pangan pada rumah tangga petani pada kedua desa adalah faktor tingkat pendapatan yang memberikan pengaruh positif sedangkan faktor jumlah tanggungan atau anggota keluarga dan tingkat pendidikan ibu tidak memberikan pengaruh terhadap ketersediaan pangan pada rumah tangga petani. 


\section{DAFTAR PUSTAKA}

Dicky. 2014. Keragaan Konsumsi Pangan Rumah Tangga Kupang Timur Kabupaten Kupang. Skripsi. Fakultas Pertanian Undana, Kupang.

Djiteng, Roedjito D. 1990. Penilaian Dan Perencanaan Konsumsi Pangan.Fakultas Pertanian, Institut Pertanian Bogor

Hardiansyah Dan Briawan. 1990. Penilaian Dan Perencanaan Konsumsi Pangan. Jurusan Gizi Masyarakat Dan Sumber Daya Keluarga. Fakultas Pertanian. IPB-Bogor.

Jutomo L. 2000 Telaah Ketersediaan Pangan Rumah Tangga Petani Di Sepanjang Sungai Cihideung, Sub-Daerah Aliran Sungai Cisadane, Kabupaten Bogor Jawa Barat.

Tameno. 2008. Tingkat Ketahanan Pangan Dalam Rumah Tangga Petani Di Desa Kusi Kecamatan Kuanfatu Kabupaten Timor Tengah Selatan.Skripsi. Fakultas Pertanian Undana, Kupang.

Tulle. 2007. Analisis Ketersediaan Dan Ketahanan Pangan Pokok Rumah Tangga Kecamatan Sulamu Kabupaten Kupang Timur. Skripsi. Fakultas Pertanian Undana, Kupang.

Undang-Undang Republik Indonesia No 18 Tahun 2012 Tentang Pangan Https://Www.Google.Co.Id/?Gws_Rd=Cr\&Ei=5akivmatgpcvuasx 7ociaq=Un dangundang+Republik+Indonesia+No+18+Tahun+2012+Tentang+Pangan).di akses tanggal 23 Februari 2017). 